\title{
Alkaline Denaturation of Bovine Serum Albumin*
}

\author{
By \\ Joji Hori**
}

\begin{abstract}
Summary
The alkaline denaturation of bovine serum albumin was studied by acrylamide gel electrophoresis at $\mathrm{pH}$ 9.0. The gel patterns were similar to those for the alkali-denatured human serum albumin, and it is concluded that there were also the "first and second reactions." The intrinsic viscosity of the alkali-denatured bovine serum albumin was determined at $\mathrm{pH} 9.0$ and $20^{\circ} \mathrm{C}$. Data obtained support this conclusion.
\end{abstract}

Key words : serum albumin, alkaline denaturation, mechanism, polyacrylamide gel, intrinsic viscosity.

\section{Introduction}

Recently, the alkaline denaturation of human serum albumin (HSA) has been studied by polyacrylamide gel electrophoresis, ${ }^{1)}$ and it was found that at the initial step of the denaturation 8-9 discrete zones appeared in the gel pattern (Fig. 1).

Zones have been numbered $1,1^{\prime}, 2^{\prime \prime}, 2^{\prime}, 2,3,4,5$, and 6 in the order of migration velocity; and it was concluded that components in zones 1 and $1^{\prime}$ are monomers, those in zones $2^{\prime \prime}, 2^{\prime}$, and 2 dimers, and those in zones 3-6 are further polymers of the albumin. The mechanism of the initial step of the alkaline denaturation was given to be :

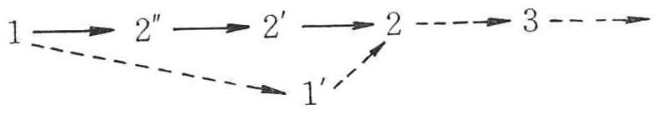

where the reaction, $1 \longrightarrow 2^{\prime \prime} \longrightarrow 2^{\prime} \longrightarrow 2$, was called the "first reaction," and the reaction, $1 \ldots \rightarrow$ $1^{\prime} \cdots \rightarrow 2 \cdots \rightarrow 3 \cdots \rightarrow$, was named the "second reaction." After the "first reaction" proceeded to a certain degree the "second reaction" occurred.

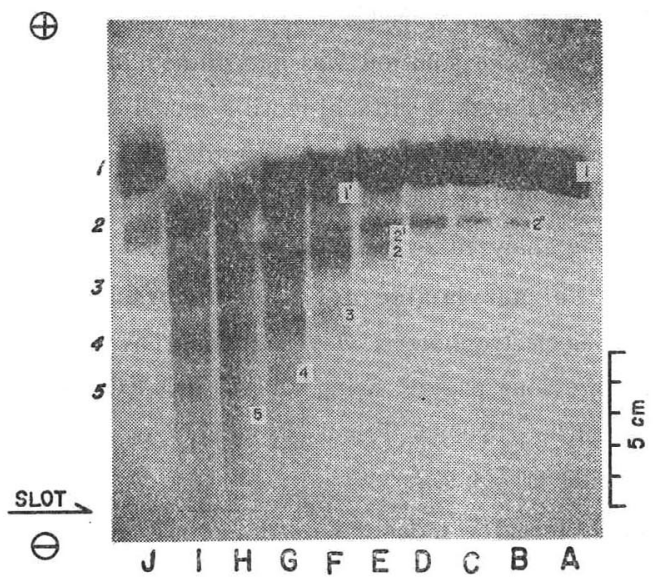

Fig. 1. Patterns of gel electrophoresis of $1 \%$ purified HSA exposed to high pH's for $2 \mathrm{hr}$. at $20^{\circ} \mathrm{C}$.

Gel concentration $5 \%$. Exposure $\mathrm{pH}$ values are : $\mathrm{B}, 10.1 ; \mathrm{C}, 10.4 ; \mathrm{D}, 11.3 ; \mathrm{E}, 11.6 ; \mathrm{F}, 11.9$; G, $12.3 ; \mathrm{H}, 12.5 ; \mathrm{I}, 12.8$. A : $1 \%$ solution of purified HSA. J : $1 \%$ solution of commercial HSA.***

* ウシ血清アルブミンのアルカリ変性.

*** 堀 襄二, 名古屋市立大学教養部化学教室.

*** Crystalline human serum albumin, Nutritional Biochemical Corp. (Control No. 5865) （受付 1980年 2 月 1 日) 
The purpose of this study is to clarify the mechanism of the initial step of the alkaline denaturation of bovine serum albumin (BSA), and studies were made by polyacrylamide gel electrophoresis at $\mathrm{pH} 9.0$ and by intrinsic viscosity measurements at $\mathrm{pH} 9.0$.

\section{Experimental}

\section{Materials}

Armour's crystalline BSA, Lot No. N 72905, was used. The content of dimer impurity was less than $8 \%$. The concentration of the albumin in aqueous solution was determined with Hitachi's Beckmantype spectrophotometer using $\mathrm{E}_{1 \mathrm{~cm}}^{1 \%}=6.67$ at $279 \mathrm{~nm}$. All other chemicals were reagent grade.

\section{Procedure of alkali treatment}

The procedure of alkali treatment was exactly the same as described previously, ${ }^{1)}$ and $1 \%$ BSA solutions of varying alkalinity (ca. $\mathrm{pH}$ 10-13) were prepared in $0.13 \mathrm{M} \mathrm{NaCl}-\mathrm{NaOH}$ solutions at $20^{\circ} \mathrm{C}$. The $\mathrm{pH}$ of the solution was determined in a stream of nitrogen with a Hitachi-Horiba model F 5 glasselectrode $\mathrm{pH}$ meter. After standing for different durations of time, an aliquot of the solution taken out was analyzed by gel electrophoresis.

\section{Polyacrylamide gel electrophoresis}

Gel electrophoresis was conducted as described in a previous paper ${ }^{1)}$ using $0.1 \mathrm{M}$ Tris-EDTA-boric acid buffer ( 0.038 м Tris-0.004 м EDTA-0.013 м bоric acid) at $\mathrm{pH} 9.0$.

\section{Viscosity measurements}

A 1\% BSA solution* (12 ml), pH 11.6, was prepared in $0.13 \mathrm{M} \mathrm{NaCl}-\mathrm{NaOH}$ solution at $20^{\circ} \mathrm{C}$. After standing for a desired time, usually 5 min.$6 \mathrm{hr}$., this was dialyzed for $20 \mathrm{hr}$. at $5^{\circ} \mathrm{C}$ against $0.1 \mathrm{M}$ carbonate buffer $\left(0.091 \mathrm{M} \mathrm{NaHCO}_{3}-0.009 \mathrm{M}\right.$ $\mathrm{Na}_{2} \mathrm{CO}_{3}$ ) or Tris-EDTA-boric acid buffer at $\mathrm{pH} 9.0$ to stop the denaturation. The dialyzed solution was concentrated by "Collodion bag" (SartoriusMembranfilter, $\mathrm{GmbH}$ ) to ca. $7 \%$. This solution was diluted to various concentrations, ca. 6, 5, 4, 3, and $2 \%$, with the buffer used for the dialysis. Viscosities of these solutions were measured with a capillary viscometer of Ostwald type at $20 \pm 0.01^{\circ} \mathrm{C}$ using $1.2 \mathrm{ml}$ of solution, and reduced and intrinsic viscosities were determined. The flow time for the viscometer was about $45.4 \mathrm{sec}$. for water. Flow times generally were reproducible within $\pm 0.05 \mathrm{sec}$.

\section{Results and discussion}

\section{Gel electrophoretic behaviour}

BSA exposed to high pH's for various periods ( 5 min. $-4 \mathrm{hr}$.) at $20^{\circ} \mathrm{C}$ was analyzed by gel electrophoresis. The patterns obtained were similar to those for the alkali-denatured HSA, and there were also the "first and second reactions." At the "second reaction," however, a new zone appeared between zone 1 and $1^{\prime}$. This zone is named $1^{\prime \prime}$. In Fig. 2, as an example, are shown patterns of BSA exposed to high pH's for $2 \mathrm{hr}$. at $20^{\circ} \mathrm{C}$. As is seen, zones $2^{\prime \prime}, 2^{\prime}$, and 2 originating from the "first reaction" were observed at $\mathrm{pH}$ 11.3. There is a possibility

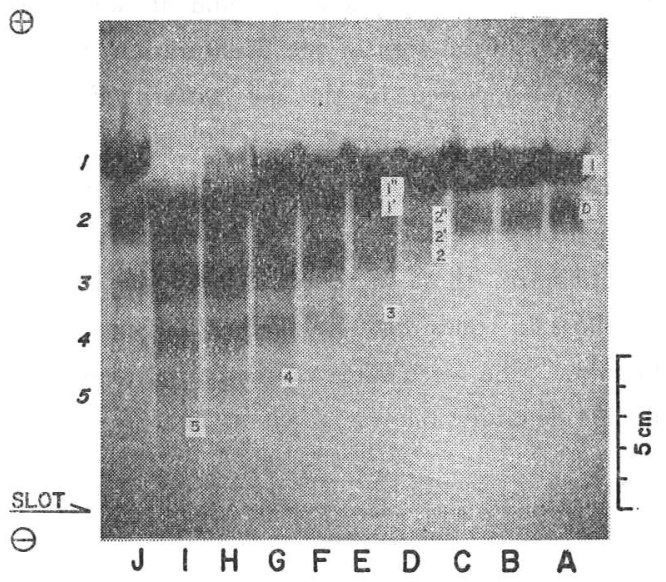

Fig. 2. Patterns of gel electrophoresis of $1 \%$ BSA exposed to high $\mathrm{pH}$ 's for $2 \mathrm{hr}$. at $20^{\circ} \mathrm{C}$.

Gel concentration $5 \%$. Exposure $\mathrm{pH}$ values are : $\mathrm{B}, 10.1 ; \mathrm{C}, 10.4 ; \mathrm{D}, 11.3 ; \mathrm{E}, 11.6 ; \mathrm{F}, 11.9$; $\mathrm{G}, 12.3 ; \mathrm{H}, 12.5 ; \mathrm{I}, 12.8$. A : $1 \%$ solution of BSA. J : $1 \%$ solution of commercial HSA.**

$* 8 \mathrm{ml}$ of $1.5 \% \mathrm{BSA}+3.44 \mathrm{ml}$ of $0.4 \mathrm{M} \mathrm{NaCl}+0.56 \mathrm{ml}$ of $0.4 \mathrm{~m} \mathrm{NaOH}$.

** Crystalline human serum albumin, Nutritional Biochemical Corp. (Control No. 5865) 
that zones $2^{\prime \prime}$ and $2^{\prime}$ also exist in the $\mathrm{pH}$ region of 10.4-10.1. The reason is as follows: The pattern of BSA involves a zone of dimer impurity (zone D in Fig. 2), and this zone is also observed at $\mathrm{pH}$ 10.4 and 10.1. Since the mobility of zones $2^{\prime \prime}$ and $2^{\prime}$ is almost equal to that of zone $\mathrm{D}$, these three zones would overlap with each other even if weak zones $2^{\prime \prime}$ and $2^{\prime}$ should exist in this $\mathrm{pH}$ region. At a $\mathrm{pH}$ above 11.6 the zone $1^{\prime \prime}$ is observed in addiion to zones $1^{\prime}$ and 3 resulting from the "second reaction." It is considered probable that new zone 1 " corresponds to the zone 1" reported by Aoki et al.,2) namely, the component in the new zone 1" may well be formed from component 1 through the intramolecular SH to S-S exchange reaction. From patterns E-I in Fig. 2, it can readily be imagined that there might be a successive reaction, $1 \longrightarrow 1^{\prime \prime}$ $\longrightarrow 1^{\prime}$. A similar reaction has been observed at the initial stage of very mild heat denaturation of BSA. ${ }^{3)}$

With the alkaline denaturation of HSA, as described in a previous paper, ${ }^{1)}$ zone $1^{11}$ could not be observed in the gel pattern. It is, however, possible that there may exist zone $1^{\prime \prime}$ as in the case of BSA. If it exists, the mobility of zone $1^{\prime \prime}$ would have a likeness to that of zone $1^{\prime}$.

\section{Viscosity behaviour}

The viscosity of BSA exposed to $\mathrm{pH} 11.6$ at $20^{\circ} \mathrm{C}$ for different durations of time was determined at $\mathrm{pH}$ 9.0. In Fig.3, as an example, are shown the reduced viscosities $\eta_{\mathrm{sp}} / \mathrm{c}$ as a function of concentration c (grams $/ 100 \mathrm{ml}$ ). A relation between intrinsic viscosity and concentration are apparantly linear between 1.5 and $6 \%$ of BSA. Fig. 4 shows how the intrinsic viscosity changes as a function of exposure time, where the upper curve was obtained in the Tris-EDTA-boric acid buffer and the lower curve in the carbonate buffer. The information obtained from the curves is as follows: (i) A considerable increase of the intrinsic viscosity was found at an exposure time above $1.5 \mathrm{hr}$. This change is an evidence for the "second reaction" following the "first reaction," as the gel electrophoresis showed that the "second reaction" occurred under the pre-

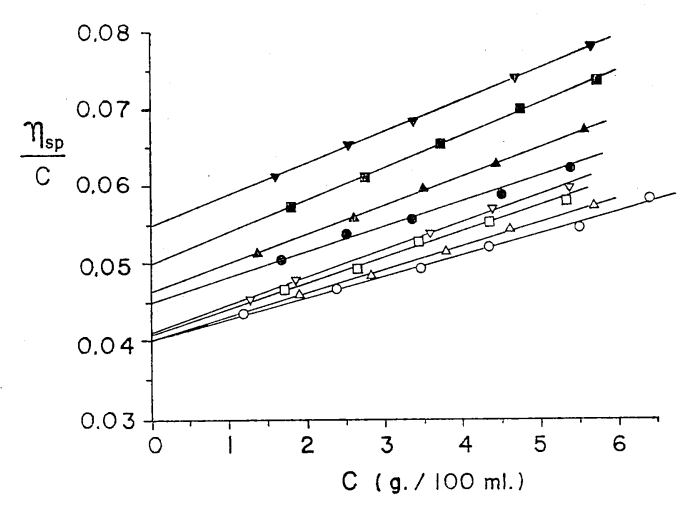

Fig. 3. Dependence of reduced viscosity on concentration for alkali-denatured BSA in $0.1 \mathrm{M}$ carbonate buffer at $\mathrm{pH} 9.0$ at $20^{\circ} \mathrm{C}$.

BSA was exposed to $\mathrm{pH} 11.6$ at $20^{\circ} \mathrm{C}$. Exposure times are : $\bigcirc, 0$ min. ; $\triangle, 15 \mathrm{~min}$; $\square, 30 \mathrm{~min}$; $\nabla, 1$ hr. ; 0, 1.5 hr. ; $\mathbf{\Delta}, 2.5$ hr. ; 4 hr. ; $6 \mathrm{hr}$.

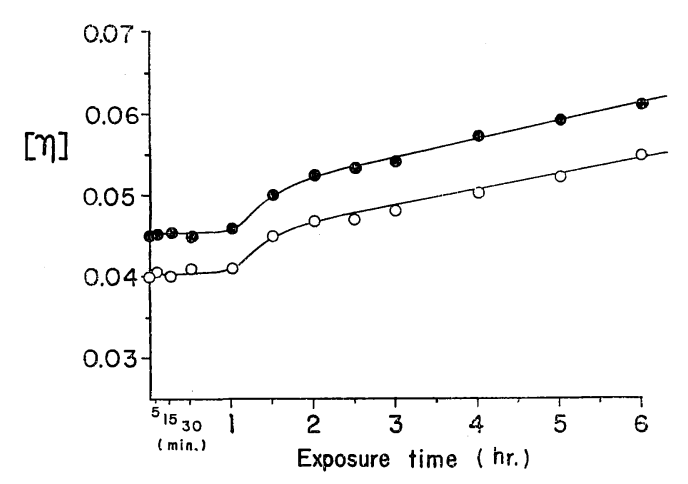

Fig. 4. Dependence of intrinsic viscosity on exposure time for alkali-denatured BSA.

BSA was exposed to $\mathrm{pH} 11.6$ at $20^{\circ} \mathrm{C}$. $\bigcirc$, data in $0.1 \mathrm{M}$ carbonate buffer at $\mathrm{pH} 9.0$ at $20^{\circ} \mathrm{C}$; - data in $0.1 \mathrm{~m}$ Tris-EDTA-boric acid buffer at $\mathrm{pH} 9.0$ at $20^{\circ} \mathrm{C}$.

sent conditions (see pattern E in Fig. 2). (ii) Strictly speaking the intrinsic viscosity was substantially the same within one hour but increased with times above $1.5 \mathrm{hr}$. These facts seem to support the interpretation given previously (ref. 1) that when the $\mathrm{pH}$ of the HSA solution was lowered from 1013 to 9 expanded components $1,2^{\prime \prime}$, and $2^{\prime}$ originating in the "first reaction" reduced their volumes reversibly and expanded components $2,3,4, \ldots \ldots$ arising from the "second reaction" did not reduce 


\section{（186）生物物理化学}

the volume. (iii) With the Tris-EDTA-boric acid buffer, intrinsic viscosity values were higher than those with the carbonate buffer. The intrinsic viscosity of native BSA at $\mathrm{pH} 9.0$ was 0.045 in the Tris-EDTA-boric acid buffer and 0.040 in the carbonate buffer, and the value in the latter seemed reasonable when compared with that reported in the literature. ${ }^{4,5)}$ The abnormally high value in the former is an evidence for the conformational change of the BSA molecule due to the effect ${ }^{6,7)}$ of the Tris-EDTA-boric acid buffer.

\section{Acknowledgement}

The author wishes to thank Dr. K. Aoki of the faculty of engineering, Gifu University for his advice and encouragement during this study.

\section{References}

1) Hori, J. : Physico-Chem. Biol. (Seibutsubutsurikagaku), 22 : 189, 1979.
2) Aoki, K. et al. : Biochim. Biophys. Acta, 328 : 323, 1973.

3) Aoki, K. et al. : Bull. Inst. Chem. Res., Kyoto Univ., 47 : 274, 1969.

4) Tanford, C. and Buzzell, J. G. : J. Phys. Chem., $60: 225,1956$.

5) Loeb, G. I. and Scheraga, H. A. : J. Phys. Chem., $60: 1633,1956$.

6) Aoki, K. and Nagaoka, S. : Biochim. Biophys. Acta, 328 : 334, 1973.

7) Aoki, K. and Foster, J.F. : Biochemistry, 14 : 3566, 1975.

要

旨

ウシ血清 alb のアルカリ変性をアクリルアミドゲル 電気泳動 $(\mathrm{pH}$ 9.0) によって研究した. 得られたゲル 泳動図はアルカリ変性したヒト血清 alb の泳動図とよ く似て和り, ウシ血清 alb の場合もヒト血清 alb の場 合と同様, “first および second reaction” が存在す るといら結論を得た. 次に,アルカリ変性したウシ血 清 alb の固有粘度を $\mathrm{pH} 9.0 ， 20^{\circ} \mathrm{C}$ 执いて測定した ところ，上の結論を支持するデータが得られた. 